REFERENCES

Bieri, J. G. \& Pollard, C. J. (1954). Brit. F. Nutr. 8, 32.

Kon, S. K., McGillivray, W. A. \& Thompson, S. Y. (1955), Brit. F. Nutr. 9, 244.

McGillivray, W. A., Thompson, S. Y. \& Worker, N. A. (1956). Brit. F. Nutr. 10, 126.

Worker, N. A. (1956). Brit. F. Nutr. 10, 169.

\title{
The utilization of aqueous dispersions of carotene by rats and of carotene and vitamin $A$ by lactating goats
}

\author{
By W. A. McGILLIVRAY and N. A. WORKER \\ Biochemistry Department, Massey Agricultural College (University of New Zealand), \\ Palmerston North, New Zealand \\ (Received 24 August 1956)
}

It is now generally accepted that orally administered carotene is converted into vitamin $A$ in the intestinal wall of all species of higher animal so far investigated (see, for example, review by Kon \& Thompson, I95I). Conflicting reports are still appearing, however, about the utilization of carotene given parenterally. In previous communications (Kon, McGillivray \& Thompson, 1955; McGillivray, Thompson \& Worker, 1956) we have shown, in agreement with earlier reports by other workers (e.g. Bieri \& Pollard, I954; Bieri, 1955a), that carotene administered intravenously as an aqueous dispersion to rats or rabbits is converted into vitamin $A$ at a site other than the intestine. About the true site of conversion Worker $(1956$, I957) has established, as originally suggested by Bieri \& Pollard (1954) and later supported by Kon et al. (1955) and McGillivray et al. (1956), that no organ is specifically involved and that conversion can probably occur in any tissue. If this is so, some conversion into vitamin $A$ of aqueous carotene dispersions administered by parenteral routes other than the intravenous might be expected, and various workers have in fact claimed restoration of growth or other disappearance of vitamin A-deficiency signs after intramuscular, intraperitoneal or subcutaneous injection of various carotene dispersions (e.g. Bieri \& Sandman, I95I; Lease, Lease, Steenbock \& Baumann, r942; Tomarelli, Charney \& Bernhart, 1946). It therefore seemed that a comparison, as indicated by hepatic vitamin A stores, of the efficiency of conversion into vitamin $\mathrm{A}$ of aqueous carotene dispersions administered by various routes, and further investigations more detailed than earlier ones of some of the factors influencing the utilization of intravenously injected carotene dispersions, might provide additional information about the mechanism and nature of the processes involved.

After the claim by Sobel, Rosenberg \& Engel (1952) that the intravenous administration of an aqueous dispersion of vitamin $A$ to lactating cows resulted in a marked increase in the vitamin A level of their milk, the effect of aqueous dispersions of vitamin A alcohol and ester and of carotene injected intravenously into lactating goats was investigated, as was also the effect of similar dispersions injected directly into the mammary gland. 
EXPERIMENTAL

General. The materials and methods used were essentially as described by Kon et al. (1955) with the modifications discussed by McGillivray et al. (1956).

Aqueous dispersions of carotene and vitamin A. These were prepared with a $20 \%(\mathrm{v} / \mathrm{v})$ solution in water of Tween 40 (polyoxyethylenesorbitan monopalmitate, Atlas Powder Co., Wilmington, Delaware) as described by Bieri \& Pollard (1954) and as used in our previous investigations. Carotene (about $88 \% \beta$-carotene) and vitamin $\mathrm{A}$ palmitate were obtained from L. Light and Co. Ltd, and $\alpha$-tocopheryl acetate and vitamin A alcohol from Eastman Kodak Ltd. Xanthophyll was extracted from fresh grass as described by McGillivray et al. (1956).

Rats. The rats were albinos of a Wistar strain rendered partially deficient in vitamin $\mathrm{A}$ as described previously (McGillivray et al. 1956). Unless otherwise stated, all injections were made into the jugular vein exposed by ventral neck incision.

Goats. The goats were of a mixed breed, predominantly Saanen and were tethered on pasture throughout the experimental period. Unless otherwise stated (Tables 4, 5) they were milked once daily. All intravenous injections were made into, and blood samples were drawn from, the jugular vein, intramammary injections were made into the tissue of the gland, the needle being withdrawn slowly during the injection to spread the dispersion through the tissue; the dose was given as two equal injections.

Determination of vitamin $A$ and carotene. All determinations were carried out as described by Thompson, Ganguly \& Kon (1949), except that, to obtain a more uniform weakening of the alumina used for chromatography, it was suspended in $8 \%$ ethanol in $n$-hexane before the column was made. During the course of this work, owing to supply problems in this country, $n$-hexane was replaced for all chromatographic work by light petroleum (b.p. $40-60^{\circ}$, British Drug Houses Ltd), comparative experiments having established that there was no difference in the behaviour of the two solvents.

The rapid and uniform pouring of the chromatographic columns was facilitated by the use of Polythene wash bottles, a convenient procedure being to fill the bottle about one-fifth with alumina and then to add an equal volume of eluent, shake, and dispense into the chromatography tubes.

Fat was extracted from the milk samples by the method of Olson, Hegsted \& Peterson (1939).

RESULTS

\section{Experiments with rats partially deficient in vitamin $A$}

Utilization of carotene dispersions administered by different routes. Table I shows the utilization of carotene dispersions administered intravenously, subcutaneously, intramuscularly, intraperitoneally and orally. The rats were killed 4 days after dosing. At this dosage level of $400 \mu \mathrm{g} /$ rat the carotene dispersion was equally well utilized, as indicated by hepatic vitamin A levels, whether injected intravenously or given orally and was almost as well utilized when injected intraperitoneally. Intramuscular injections of carotene were about one-third as well utilized as intravenous, but subcutaneous injections did not increase hepatic levels of vitamin A. At slaughter large 
quantities of carotene remained at the site of intramuscular and subcutaneous injection, that at the latter representing the bulk of the dose.

Effect of dosage level, interval between dosing and killing and repeated dosing on the utilization of carotene dispersions administered intravenously. The effects are shown in Table 2 (Exps. I-4). These experiments illustrate the variation in behaviour experienced with different samples of aqueous carotene dispersions. Exps. 2 and 3 were carried out with the same batch of carotene dispersion; in Exps. I and 4 two different dispersions were used. All dispersions were prepared in the same way, the only difference being that the dispersion used in Exp. I was prepared from a sample of carotene that had been in use for some time (although always stored at $0^{\circ}$ under nitrogen when not in use, and showing no obvious signs of decomposition), whereas the other dispersions

Table I. Utilization of aqueous carotene dispersions in Tween ( $400 \mu \mathrm{g}$ carotene $/ 0.4 \mathrm{ml}$. dispersion) administered by various routes to male rats of mean weight $240 \mathrm{~g}$, killed 4 days after dosing

\begin{tabular}{|c|c|c|c|c|c|}
\hline \multirow[b]{3}{*}{$\begin{array}{l}\text { No. of } \\
\text { rats } \\
\text { used }\end{array}$} & \multirow[b]{3}{*}{$\begin{array}{c}\text { Route of } \\
\text { administration } \\
\text { of carotene }\end{array}$} & \multicolumn{4}{|c|}{ Total liver content } \\
\hline & & \multicolumn{3}{|c|}{ Vitamin A } & \multirow[b]{2}{*}{$\begin{array}{l}\text { Carotene } \\
(\mu \mathrm{g})\end{array}$} \\
\hline & & $\begin{array}{l}\text { Alcohol } \\
\qquad(\mu \mathrm{g})\end{array}$ & $\begin{array}{c}\text { Ester } \\
(\mu \mathrm{g})\end{array}$ & $\begin{array}{l}\text { Total } \\
(\mu \mathrm{g})\end{array}$ & \\
\hline 3 & - & 0.4 & 0.7 & $I \cdot I$ & $\circ$ \\
\hline 6 & Intravenous & $2 \cdot 5$ & I $\mathbf{I}$ & 14 & 36 \\
\hline 3 & Subcutaneous & 0.4 & 0.9 & $1 \cdot 3$ & $4 \cdot 2$ \\
\hline 3 & Intramuscular & 0.5 & $2 \cdot 8$ & $3 \cdot 3$ & 14 \\
\hline 3 & Intraperitoneal & $I \cdot O$ & $9 \cdot 7$ & I I & 18 \\
\hline 3 & Oral & $3 \cdot 3$ & ro & I 3 & $5 \cdot 0$ \\
\hline
\end{tabular}

were prepared from a freshly opened ampoule of carotene. It is apparent from the table that the dispersions differed in the total amount of vitamin A formed, in the ratio of vitamin A alcohol to ester in the liver and in the amount of carotene in the liver. Though the differences may be explained by the different samples of carotene used, a comparison of results presented in Tables $\mathrm{I}-4$ and in our previous communications (McGillivray et al. 1956; Worker, 1956) shows that similar differences frequently occurred between dispersions sometimes prepared from the same sample of carotene. As stated previously (McGillivray et al. 1956), we have no explanation to offer unless these differences represent differences in the degree of dispersion of the carotene. They cannot be attributed to individuality since the levels of carotene and vitamin $A$ in the blood and livers of rats injected with samples of the same dispersion were remarkably constant. However, throughout this investigation, when comparisons were made between various treatments the same dispersion was used throughout any one experiment.

It is apparent from Exps. I and 2 (Table 2) that measurable amounts of vitamin A were stored in the liver after the intravenous injection of as little as $10 \mu \mathrm{g}$ carotene and that the hepatic stores of both carotene and vitamin A increased more or less directly with dosage level up to $800 \mu \mathrm{g}$ carotene, the highest level investigated. If allowance is made for the fact that, with the dispersion used in Exp. 4, $22 \mu \mathrm{g}$ vitamin A were stored 
in the liver from a dose of $400 \mu \mathrm{g}$ carotene as compared with $37 \mu \mathrm{g}$ from the same dose level of another dispersion in Exps. 2 and 3 , then it would seem that there was little difference in the utilization of the carotene whether the dispersion was given as a single injection or as smaller injections at $24 \mathrm{~h}$ intervals. In Exp. 3, liver vitamin A levels showed a steady increase with time up to $24 \mathrm{~h}$ after injection, but maximum carotene storage was obtained after $3 \mathrm{~h}$.

Table 2. Effect of dose level (Exps. I and 2), interval between dosing and killing (Exp. 3) and repeated dosing (Exp. 4) on the utilization of aqueous carotene dispersions in Tween intravenously injected into female rats of mean weight $250 \mathrm{~g}$

\begin{tabular}{|c|c|c|c|c|c|c|c|c|c|}
\hline \multirow[b]{3}{*}{$\begin{array}{l}\text { Exp. } \\
\text { no. }\end{array}$} & \multirow[b]{3}{*}{$\begin{array}{c}\text { No. of } \\
\text { rats } \\
\text { used }\end{array}$} & \multirow{3}{*}{$\begin{array}{l}\text { Amount of } \\
\text { carotene } \\
\text { injected } \\
(\mu \mathrm{g})\end{array}$} & \multirow{3}{*}{$\begin{array}{c}\text { Time } \\
\text { between } \\
\text { injection and } \\
\text { slaughter } \\
\text { (h) }\end{array}$} & \multirow{2}{*}{\multicolumn{2}{|c|}{ Blood plasma }} & \multicolumn{4}{|c|}{ Total liver content } \\
\hline & & & & & & \multicolumn{3}{|c|}{ Vitamin A } & \multirow[b]{2}{*}{$\begin{array}{c}\text { Carotene } \\
(\mu \mathrm{g})\end{array}$} \\
\hline & & & & $\begin{array}{c}\text { Vitamin } A \\
\text { alcohol } \\
(\mu \mathrm{g} / 100 \mathrm{ml} .)\end{array}$ & $\begin{array}{c}\text { Carotene } \\
(\mu \mathrm{g} / 100 \mathrm{ml} .)\end{array}$ & $\begin{array}{l}\text { Alcohol } \\
\quad(\mu \mathrm{g})\end{array}$ & $\begin{array}{c}\text { Ester } \\
(\mu \mathrm{g})\end{array}$ & $\begin{array}{l}\text { Total } \\
(\mu \mathrm{g})\end{array}$ & \\
\hline Control & 6 & - & - & 12 & 一 & 0.3 & 0.6 & 0.9 & $\circ$ \\
\hline \multirow[t]{5}{*}{1} & 2 & Io & 24 & I 3 & Not detectable & $1 \cdot 0$ & $1 \cdot 2$ & $2 \cdot 2$ & 4 \\
\hline & 2 & 20 & 24 & 12 & Not detectable & 0.8 & $\mathbf{I} \cdot 7$ & $2 \cdot 5$ & 6 \\
\hline & 2 & 40 & 24 & 13 & Trace & $I \cdot 0$ & $2 \cdot 4$ & $3 \cdot 4$ & 14 \\
\hline & 2 & 75 & 24 & 14 & Trace & $\mathbf{I} \cdot \mathbf{I}$ & 5.0 & $6 \cdot 1$ & 27 \\
\hline & 2 & 150 & 24 & 13 & Trace & $I \cdot 2$ & I3 & 14 & 52 \\
\hline \multirow[t]{6}{*}{2} & 3 & 25 & 24 & 13 & Not detectable & 0.2 & $3 \cdot 5$ & $3 \cdot 7$ & 4 \\
\hline & 3 & $5 \circ$ & 24 & 12 & Not detectable & 0.3 & $5 \cdot 7$ & $6 \cdot 0$ & 19 \\
\hline & 3 & 100 & 24 & 14 & Trace & 0.5 & $6 \cdot 0$ & $6 \cdot 5$ & 32 \\
\hline & 3 & 200 & 24 & 13 & Trace & $2 \cdot 3$ & 12 & I4 & 33 \\
\hline & 3 & 400 & 24 & 12 & c. 25 & $4 \cdot 7$ & 32 & 37 & 64 \\
\hline & 3 & 800 & 24 & 12 & c. 50 & $4 \cdot 2$ & 40 & 44 & 160 \\
\hline \multirow[t]{7}{*}{3} & 3 & 400 & 3 & 67 & $375^{\circ}$ & $1 \cdot 3$ & 12 & 13 & 63 \\
\hline & 3 & 400 & 6 & 23 & $3^{80}$ & $I \cdot O$ & 13 & 14 & 60 \\
\hline & 3 & 400 & 12 & 19 & 180 & $2 \cdot 7$ & 20 & 23 & $6 I$ \\
\hline & 3 & 400 & 18 & 16 & 35 & $2 \cdot 0$ & 24 & 26 & 60 \\
\hline & 3 & 400 & 24 & 12 & 25 & 4.7 & 32 & 37 & 64 \\
\hline & 3 & 400 & 48 & I3 & Trace & $3 \cdot 5$ & 33 & 37 & 62 \\
\hline & 3 & 400 & 96 & ro & Trace & $I \cdot I$ & 43 & 44 & 65 \\
\hline \multirow[t]{3}{*}{4} & 3 & 400 & 24 & 14 & Trace & $8 \cdot I$ & 14 & 22 & 70 \\
\hline & 3 & $\begin{array}{l}400+400 \\
24 \mathrm{~h} \text { later }\end{array}$ & $\begin{array}{l}48 \text { from first } \\
\text { injection }\end{array}$ & 16 & Trace & 10 & 22 & 32 & I 10 \\
\hline & 3 & $\begin{array}{l}200,200+ \\
400^{*} \text { at } 24 \\
\text { intervals }\end{array}$ & $\begin{array}{l}72 \text { from first } \\
\text { injection }\end{array}$ & 15 & Trace & $4 \cdot 0$ & 23 & 27 & 66 \\
\hline
\end{tabular}

Effect of tocopherol, xanthophyll and benzoyl peroxide on the utilization of carotene dispersions administered intravenously. That the simultaneous intravenous administration of tocopherol or xanthophyll inhibited the conversion of carotene dispersion into vitamin $A$ is shown in Table 3 . Since an anti-oxidant such as tocopherol exerts an inhibitory effect, it seemed possible that a pro-oxidant such as benzoyl peroxide might have the opposite effect. However, this was not so, the addition of benzoyl peroxide also markedly reducing the amount of vitamin A stored in the livers. 
Table 3. Effect of tocopherol, xanthophyll and benzoyl peroxide on the utilization of aqueous carotene dispersions in Tween intravenously injected into female rats, of mean average weight $300 \mathrm{~g}$, killed $24 h$ after injection

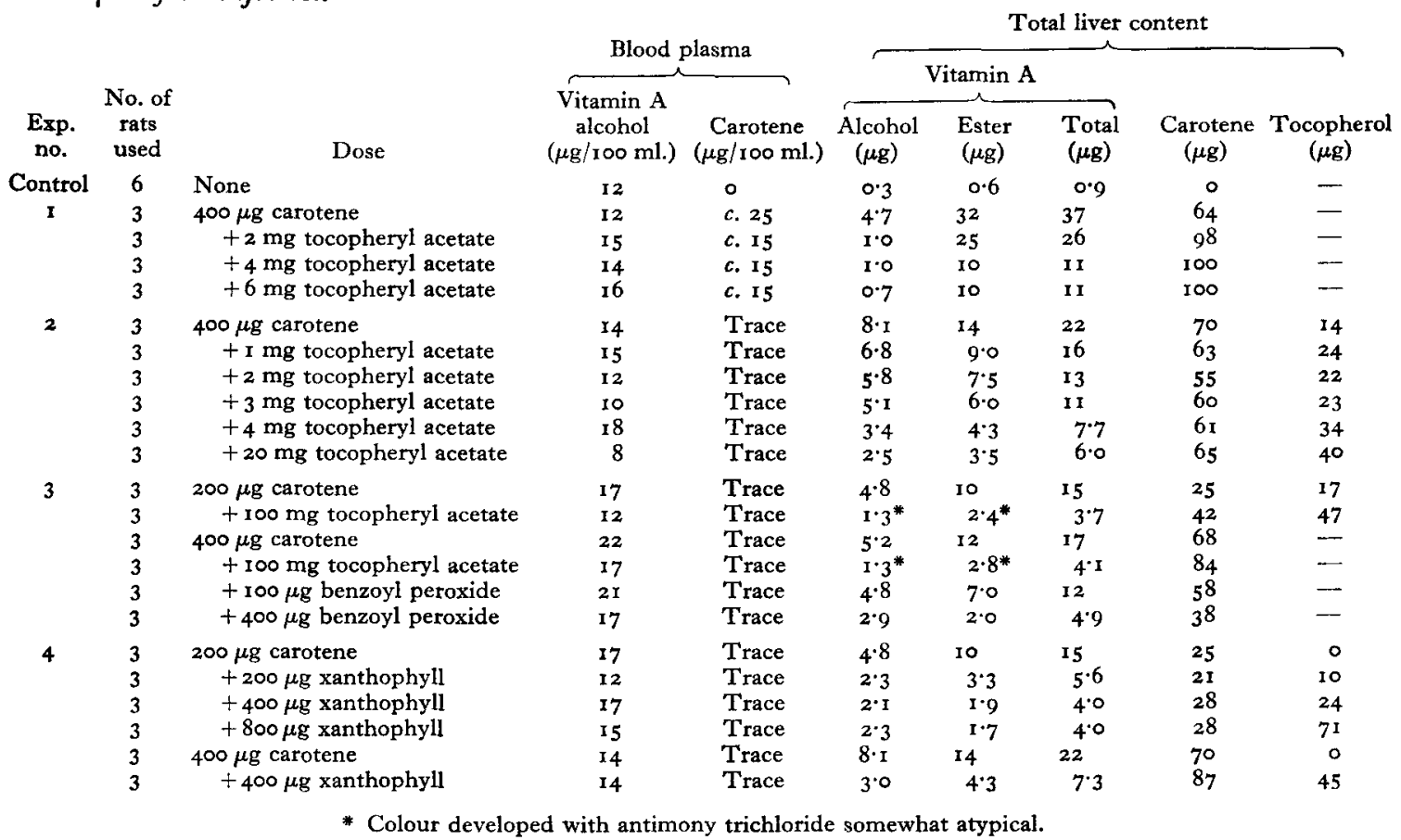

\section{Experiments with lactating goats}

From the results presented in Table 4 it is clear that, although relatively high blood plasma levels were attained, no carotene was transferred to the milk after intravenous administration of carotene dispersions, nor was the level of vitamin A alcohol or ester in the milk measurably increased by any vitamin that may have been formed from the carotene. Similarly, there was little indication of the transfer to the milk of intravenously administered vitamin $A$ alcohol or palmitate. In Exps. 2 and, particularly, 3 there was some increase in vitamin A alcohol but, considering the level of vitamin A alcohol injected, the effect was slight.

The blood plasma alcohol and ester levels in Exp. 4 indicate that, as has been reported previously for Tween dispersion of vitamin A acetate injected into rats, rabbits and calves (Kon et al. 1955), vitamin A palmitate was rapidly hydrolysed also in goats. It was also rapidly destroyed in or removed from the blood plasma, both alcohol and ester levels having returned to normal within $2 \mathrm{~h}$. The equally rapid esterification of vitamin A alcohol, as shown by plasma levels in Exps. 2 and 3, indicates an equilibrium reaction.

In marked contrast to intravenous administration, injection of carotene dispersions directly into the tissue of the mammary gland gave some indication, as shown in Table 5 (Exps. I-3), of conversion into vitamin A, the alcohol level in the milk always 
increasing. In Exp. 3, $5 \mathrm{ml}$. of a $20 \%$ Tween solution were injected into the control gland at the same time as the injection of carotene dispersion into the treated gland. The results indicate that the increases in milk vitamin $A$ alcohol were associated with the carotene and did not result from an infiltration of blood plasma vitamin $\mathrm{A}$ alcohol after tissue damage due to the Tween injection.

Table 4. Utilization of aqueous dispersions in Tween of carotene and of vitamin $A$ alcohol and palmitate injected intravenously into lactating goats

\begin{tabular}{|c|c|c|c|c|c|c|c|c|c|c|c|}
\hline \multirow[b]{3}{*}{$\begin{array}{l}\text { Exp. } \\
\text { no. }\end{array}$} & \multirow[b]{3}{*}{$\begin{array}{l}\text { No. of } \\
\text { goats } \\
\text { used }\end{array}$} & \multirow[b]{3}{*}{$\begin{array}{l}\text { Dose of } \\
\text { dispersion } \\
\text { (ml.) }\end{array}$} & & & & \multicolumn{3}{|c|}{ Blood plasma } & \multicolumn{3}{|c|}{ Milk fat } \\
\hline & & & \multicolumn{2}{|c|}{ Substance } & \multirow{2}{*}{$\begin{array}{c}\text { Time } \\
\text { after } \\
\text { injection } \\
\text { (h) }\end{array}$} & \multicolumn{2}{|c|}{ Vitamin A } & \multirow[b]{2}{*}{$\begin{array}{c}\text { Carotene } \\
(\mu \mathrm{g} / \mathrm{r} 00 \mathrm{ml} .)\end{array}$} & \multicolumn{2}{|c|}{ Vitamin A } & \multirow[b]{2}{*}{$\begin{array}{r}\text { Caroten } \\
(\mu \mathrm{g} / \mathrm{g})\end{array}$} \\
\hline & & & Nature & $\begin{array}{l}\text { Amount } \\
(\mathrm{mg})\end{array}$ & & $\begin{array}{c}\text { Alcohol } \\
(\mu \mathrm{g} / \mathrm{ro0} \mathrm{ml} .)\end{array}$ & $\begin{array}{c}\text { Ester } \\
(\mu \mathrm{g} / 100 \mathrm{ml} .)\end{array}$ & & $\begin{array}{c}\text { Alcohol } \\
(\mu \mathrm{g} / \mathrm{g})\end{array}$ & $\begin{array}{l}\text { Ester } \\
(\mu \mathrm{g} / \mathrm{g})\end{array}$ & \\
\hline $\mathbf{I}$ & 3 & $\begin{array}{c}0^{*} \\
10-60\end{array}$ & Carotene & $10-60$ & $\underset{2-96}{-}$ & $\begin{array}{l}3 x-62 \\
29-52\end{array}$ & $\begin{array}{l}6-8 \\
6-8\end{array}$ & Up to 1720 & $\begin{array}{l}0.2-0.4 \\
0.2-0.4\end{array}$ & $\begin{array}{l}14-18 \\
14-18\end{array}$ & $\stackrel{\circ}{\circ}$ \\
\hline 2 & I & $\begin{array}{c}0^{*} \\
20\end{array}$ & $\underset{\substack{\text { Vitamin A A } \\
\text { alcohol }}}{-}$ & $\overline{20}$ & $\begin{array}{r}-\frac{1}{12} \\
4 \\
24 \\
48\end{array}$ & $\begin{array}{r}47 \\
350 \\
44 \\
42 \\
46\end{array}$ & $\begin{array}{r}5 \cdot 0 \\
\times 75 \\
4.5 \\
3.7 \\
4.1\end{array}$ & $\begin{array}{l}0 \\
0 \\
0 \\
0 \\
0\end{array}$ & $\begin{array}{l}0.4 \\
- \\
0.5 \\
0.3 \\
0.3\end{array}$ & $\begin{array}{l}14 \\
17 \\
14 \\
15\end{array}$ & $\begin{array}{l}0 \\
0 \\
0 \\
0\end{array}$ \\
\hline 3 & $\mathbf{I}$ & 10* & 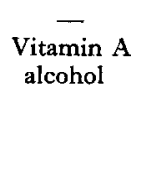 & ro & $\begin{array}{r}\overline{1} \\
\frac{1}{12} \\
\frac{1}{2} \\
1 \\
2 \\
4\end{array}$ & $\begin{array}{r}51 \\
165 \\
68 \\
52 \\
49 \\
49\end{array}$ & $\begin{array}{c}3 \cdot 0 \\
41 \\
8 \cdot 7 \\
5 \cdot 1 \\
2 \cdot 9 \\
3 \cdot 4\end{array}$ & $\begin{array}{l}0 \\
0 \\
0 \\
0 \\
0 \\
0\end{array}$ & $\begin{array}{l}0.3 \\
- \\
- \\
0.9 \\
0.5\end{array}$ & $\begin{array}{l}\frac{19}{-} \\
\frac{-}{18} \\
18\end{array}$ & $\begin{array}{l}0 \\
- \\
- \\
0 \\
0\end{array}$ \\
\hline 4 & $\mathbf{I}$ & $\begin{array}{l}\text { o* } \\
\text { 10 }\end{array}$ & $\begin{array}{c}\text { Vitamin A } \\
\text { palmitate }\end{array}$ & ro & $\begin{array}{r}\overline{\frac{1}{2}} \\
\frac{1}{2} \\
1 \\
2 \\
4\end{array}$ & $\begin{array}{l}44 \\
59 \\
52 \\
44 \\
42 \\
42\end{array}$ & $\begin{array}{c}8 \cdot 2 \\
280 \\
79 \\
24 \\
9 \cdot 3 \\
8 \cdot 5\end{array}$ & $\begin{array}{l}0 \\
0 \\
0 \\
0 \\
0 \\
0\end{array}$ & $\begin{array}{l}0.3 \\
- \\
- \\
0.5 \\
0.5\end{array}$ & $\begin{array}{l}18 \\
- \\
- \\
19 \\
17\end{array}$ & $\begin{array}{l}0 \\
\\
\\
0 \\
0\end{array}$ \\
\hline
\end{tabular}

Hydrolysis of vitamin A palmitate is again apparent from Exp. 5 and some esterification of vitamin A alcohol from Exp. 4. The appearance in the milk, and the continued secretion of carotene and vitamin A, in Exps. 3-5 is not surprising and is not contradictory to the results obtained after intravenous administration. By the former route some of the dose would be injected directly into alveoli and ducts, where, owing to local blockage, it could be retained for some time before release. The permeability of membranes to the aqueous dispersions would, therefore, not be involved.

\section{DISCUSSION}

From the results presented in Table $\mathrm{I}$ it is clear that carotene in aqueous dispersion was converted into vitamin $A$ by rats when injected intraperitoneally or intramuscularly as it was when injected intravenously. There was, however, no significant increase in liver vitamin $\mathrm{A}$ after subcutaneous injection. At slaughter, 4 days after dosing, no measurable amounts of carotene were present in any of the blood-plasma samples and it is probable, from the low level present in the liver, that measurable concentrations of carotene were not attained in the blood plasma at any stage after subcutaneous injection. This may be significant, since it would appear from Table 2 (Exp. 3 ) that 
liver levels of vitamin A continue to increase only as long as reasonable levels of carotene remain in the blood plasma. These results and those obtained previously (Kon et al. 1955; McGillivray et al. 1956; Worker, 1956, 1957) further suggest that, as long as a reasonably high level of carotene remains in the plasma, vitamin $A$ is formed at some extrahepatic site and transported to the liver via the blood as vitamin $A$ alcohol. There was no significant increase in liver vitamin A after plasma vitamin A levels had returned to normal, although the liver still contained large quantities of carotene.

Table 5. Utilization of aqueous dispersions in Tween of carotene and of vitamin $A$ alcohol and palmitate injected directly into the tissue of the mammary gland of lactating goats

(Dose: $5 \mathrm{mg}$ substance in $5 \mathrm{ml}$. dispersion)

\begin{tabular}{|c|c|c|c|c|c|c|c|c|}
\hline & & & & & & Milk fat & & \\
\hline & & & & Contro & land* & & eated $\mathrm{g}$ & \\
\hline & & & & Vita & $A$ & Vita & $\mathrm{A}$ & \\
\hline $\begin{array}{c}\text { Exp. } \\
\text { no. }\end{array}$ & $\begin{array}{l}\text { goats } \\
\text { used }\end{array}$ & Substance & $\begin{array}{l}\text { injection } \\
\text { (h) }\end{array}$ & $\begin{array}{c}\text { Alcohol } \\
(\mu \mathrm{g} / \mathrm{g})\end{array}$ & $\begin{array}{l}\text { Ester } \\
(\mu \mathrm{g} / \mathrm{g})\end{array}$ & $\begin{array}{c}\text { Alcohol } \\
(\mu \mathrm{g} / \mathrm{g})\end{array}$ & $\begin{array}{l}\text { Ester } \\
(\mu \mathrm{g} / \mathrm{g})\end{array}$ & $\begin{array}{c}\text { Carotene } \\
(\mu \mathrm{g} / \mathrm{g})\end{array}$ \\
\hline $\mathbf{I}$ & I & $\begin{array}{l}\text { Nonet } \\
\text { Carotene }\end{array}$ & $\begin{array}{l}- \\
24 \\
48\end{array}$ & $\begin{array}{l}0.3 \\
0.6 \\
0.2\end{array}$ & $\begin{array}{l}17 \\
16 \\
17\end{array}$ & $\begin{array}{l}0 \cdot 5 \\
2 \cdot 2 \\
I \cdot 2\end{array}$ & $\begin{array}{l}17 \\
16 \\
18\end{array}$ & $\begin{array}{r}0 \\
420 \\
170\end{array}$ \\
\hline 2 & I & $\begin{array}{l}\text { Nonet } \\
\text { Carotene } \\
\text { Carotenef }\end{array}$ & $\begin{array}{r}- \\
4 \\
24 \\
48 \\
72\end{array}$ & $\begin{array}{l}0.4 \\
0.3 \\
0.4 \\
0.5\end{array}$ & $\begin{array}{l}18 \\
14 \\
16 \\
16\end{array}$ & $\begin{array}{l}0.4 \\
I \cdot 0 \\
I \cdot 6 \\
I \cdot 3\end{array}$ & $\begin{array}{l}16 \\
17 \\
16 \\
16\end{array}$ & $\begin{array}{r}\circ \\
380 \\
160 \\
180 \\
110\end{array}$ \\
\hline 3 & I & $\begin{array}{l}\text { Nonet } \\
\text { Carotene }\end{array}$ & $\begin{array}{r}- \\
6 \\
24 \\
48 \\
72\end{array}$ & $\begin{array}{l}0.3 \\
0.2 \\
0.2 \\
0.3 \\
0.3\end{array}$ & $\begin{array}{l}14 \\
14 \\
13 \\
14 \\
15\end{array}$ & $\begin{array}{l}0.4 \\
I .4 \\
I \cdot 0 \\
0.8 \\
0.4\end{array}$ & $\begin{array}{l}14 \\
15 \\
15 \\
12 \\
\text { I } 6\end{array}$ & $\begin{array}{r}0 \\
340 \\
110 \\
21 \\
7\end{array}$ \\
\hline 4 & I & $\begin{array}{l}\text { Nonet } \\
\text { Vitamin A } \\
\text { alcohol }\end{array}$ & $\begin{array}{l}- \\
24 \\
48 \\
96\end{array}$ & $\frac{-}{-}$ & - & $\begin{array}{l}0.2 \\
5.0 \\
4.0 \\
0.3\end{array}$ & $\begin{array}{l}16 \\
21 \\
20 \\
18\end{array}$ & $\begin{array}{l}0 \\
0 \\
0 \\
0\end{array}$ \\
\hline 5 & I & $\begin{array}{l}\text { Nonet } \\
\text { Vitamin A } \\
\text { palmitate }\end{array}$ & $\begin{array}{r}\bar{I} 8 \\
42 \\
66 \\
\text { I } 68\end{array}$ & $\begin{array}{c}- \\
- \\
-\end{array}$ & $\begin{array}{l}- \\
- \\
-\end{array}$ & $\begin{array}{c}0.2 \\
22 \\
8.4 \\
4.5 \\
0.2\end{array}$ & $\begin{array}{r}16 \\
780 \\
280 \\
140 \\
18\end{array}$ & $\begin{array}{l}0 \\
0 \\
0 \\
0 \\
0\end{array}$ \\
\hline
\end{tabular}

Further, the high blood plasma vitamin A alcohol levels attained in as little as 5 min after injection of carotene dispersions (e.g. Kon et al. 1955; McGillivray et al. 1956) indicate an extremely rapid conversion. In contrast, the relatively slow increase in liver vitamin A (as shown, for example, in Table 2, Exp. 3) would suggest that there is no similar rapid reaction in the liver. Worker (1956) has already shown that hepatectomized animals are still capable of converting intravenously administered carotene into vitamin $\mathrm{A}$, and it would seem from the foregoing that in the intact animal also the liver is an unimportant site of conversion. 
Since no specific organ appears to be involved, the failure to detect some conversion after subcutaneous injection is surprising. The possibility cannot be overlooked, however, that the conversion occurs, or is at least initiated, in the blood rather than in the tissues themselves, a random oxidation resulting in a fragment, such as, for example, retinene, that can be readily converted into vitamin $A$. The similar rates of removal of other carotenoid pigments, including those not converted into vitamin A (McGillivray et al. 1956), and of carotene from the blood of rats, rabbits and calves (although as discussed by Kon et al. (I955) the last do not form vitamin A) would support the idea of a random oxidation rather than a specific reaction producing vitamin $\mathrm{A}$.

Whatever the reaction involved, there do seem to be marked similarities between the mechanism of breakdown after oral or intravenous administration of carotene. This similarity is evident from the utilization of the various carotenoid pigments (McGillivray et al. 1956), and it is significant that in the present investigation substances such as tocopherol and xanthophyll, which are known to affect the utilization of orally administered carotene, should be found to exert a similar effect on intravenous administration.

The sparing effect of tocopherol on carotene administered orally has been demonstrated by a number of workers (e.g. Hickman, Kaley \& Harris, 1944a, $b$; Harris, Kaley \& Hickman, 1944), but it is also established that higher levels of tocopherol (of the order of $5 \mathrm{mg} / \mathrm{rat}$ daily) depress the utilization of carotene as measured both by growth rate and by liver storage of vitamin A in rats (e.g. Johnson \& Baumann, r948). A similar decreased utilization of intravenously administered carotene associated with the simultaneous injection of tocopherol is clearly apparent from Table 3 (Exps. I-3). Even as little as $\mathbf{r} \mathrm{mg}$ tocopheryl acetate had a marked effect on liver vitamin A, decreasing the amounts of both alcohol and ester forms. The anti-oxidant properties of tocopherol would explain this inhibiting effect if the mechanism of the conversion of carotene into vitamin A involves oxidation. The effect of benzoyl peroxide in also reducing liver storage of vitamin $A$ could be due to a different type of oxidation. It is possible that the inhibitory effect of tocopherol on the mechanism of conversion is apparent only when tocopherol and carotene are administered simultaneously since Bieri $\left(\mathrm{I} 955^{b}\right)$ could show no such effect when carotene was injected $24 \mathrm{~h}$ or longer after oral dosing with tocopherol.

Kelley \& Day (I950) have shown that rats given by mouth xanthophyll along with carotene stored less vitamin A in their livers than those given carotene alone. Exp. 4 (Table 3) shows that the simultaneous administration of xanthophyll produced a similar decrease in hepatic stores. No explanation is offered for this effect on the conversion of intravenously administered carotene, but it would suggest that in oral administration the effect of xanthophyll may be more intimately associated with the mechanism of conversion than with the initial absorption of the carotene.

Except for dosage level, the various factors investigated appear to have little influence on the amount of carotene taken up by the liver. The level of carotene bears a fairly definite relationship to the dose injected (Table 2, Exps. I and 2), but shows surprisingly little change from 3 to $96 \mathrm{~h}$ after injection (Exp. 3) and is not markedly influenced by either tocopherol or xanthophyll. It is difficult to advance any simple 
explanation for the levels of carotene found in the livers in, for example, Exps. 2 and 3 , in which the same dispersion was used. No simple equilibrium between plasma carotene and liver carotene, whether or not followed by a change in the physical nature of the liver carotene that prevents its subsequent release into the plasma as the level there decreases, seems compatible with the results obtained under the conditions of decreasing plasma carotene levels after the various initial levels injected. It has already been shown, however (Kon et al. 1955), that larger particles, such as are present in colloidal dispersions, are rapidly taken up by the liver and are not subsequently released into the plasma. Tween dispersions of carotene probably contain particles of a wide range of size, and a possible explanation for the liver carotene levels obtained is that all the carotene present as larger particles is removed rapidly, and retained, by the liver and possibly by other tissues. Thus differences in liver carotene levels obtained with the various dispersions used would, as suggested earlier, represent genuine differences in the physical state of these dispersions.

Our results with lactating goats do not confirm the findings of Sobel et al. (1952), who found, with cows, a marked increase in milk vitamin $A$ after intravenous administration of an aqueous dispersion of vitamin $A$, and it would appear that the goat mammary-gland membrane is impermeable to Tween dispersions. The differences between our results and those of Sobel et al. may represent a species difference, but may more likely be attributed to the difference in the type of dispersion used, since in an isolated experiment by us the intravenous injection into a cow of $10 \mathrm{mg}$ vitamin $\mathrm{A}$ alcohol as an aqueous dispersion with Tween 40 failed to produce any change in the level of vitamin $\mathrm{A}$ in the milk.

\section{SUMMARY}

I. The utilization of aqueous dispersions of carotene and vitamin $A$ in Tween $4^{\circ}$ (polyoxyethylenesorbitan monopalmitate) has been investigated in rats and lactating goats.

2. Hepatic vitamin A stores were increased in rats by the intravenous, intramuscular, intraperitoneal or oral administration of carotene dispersions, but not by subcutaneous injection.

3. There was a fairly direct relationship between the level of carotene and vitamin $A$ in the liver and the amount of carotene injected. Liver stores of vitamin A continued to increase as long as measurable amounts of carotene remained in the blood plasma, but liver levels of carotene remained constant after $3 \mathrm{~h}$.

4. It is suggested that the conversion of intravenously administered carotene dispersions into vitamin A results primarily from a random oxidation of the carotene and that at least the initial stages of the oxidation may occur in the blood.

5. Lower hepatic stores of vitamin A resulted from the simultaneous intravenous injection of xanthophyll or of relatively large amounts of tocopherol with the carotene, and attention is drawn to the apparent similarity in the mechanism of breakdown of carotene after oral or intravenous administration.

6. It is suggested that the carotene present in the liver after intravenous administration merely represents that fraction of the dose present as larger particles. 
7. Intravenous administration of aqueous dispersions of carotene or of vitamin $A$ to lactating goats had no significant effect on the level of vitamin A in the milk. When they were inserted directly into the tissue of the mammary gland there was some evidence of conversion of carotene into vitamin $A$.

We are grateful to the Department of Scientific and Industrial Research for a grant towards this investigation, which forms a section of a thesis submitted by one of us (N. A. W.) in partial fulfilment of the requirements for the degree of Ph.D. of the University of New Zealand. We also wish to thank Miss Fay Frecklington for help with much of the experimental work.

\section{REFERENCES}

Bieri, J. G. (1955a). Arch. Biochem. Biophys. 56, 90.

Bieri, J. G. (1955b). Proc. Soc. exp. Biol., N. Y., 88, 482.

Bieri, J. G. \& Pollard, C. J. (1954). Brit. F. Nutr. 8, 32.

Bieri, J. G. \& Sandman, R. P. (1951). Proc. Soc. exp. Biol., N.Y., 77, 617.

Harris, P. L., Kaley, M. W. \& Hickman, K. C. D. (1944). F. biol. Chem. 152, 313.

Hickman, K. C. D., Kaley, M. W. \& Harris, P. L. (1944a). F. biol. Chem. 152, 303.

Hickman, K. C. D., Kaley, M. W. \& Harris, P. L. (1944b). F. biol. Chem. I52, 32 I.

Kelley, B. \& Day, H. G. (1950). I. Nutr. 40, I 59.

Johnson, R. M. \& Baumann, C. A. (1948). F. biol. Chem. I75, 8 г r.

Kon, S. K., McGillivray, W. A. \& Thompson, S. Y. (I955). Brit. F. Nutr. 9, 244.

Kon, S. K. \& Thompson, S. Y. (1951). Brit. F. Nutr. 5, I I4.

Lease, J. G., Lease, E. J., Steenbock, H. \& Baumann, C. A. (1942). F. Lab. clin. Med. $27,502$.

McGillivray, W. A., Thompson, S. Y. \& Worker, N. A. (1956). Brit. J. Nutr. ro, 126.

Olson, F. R., Hegsted, D. M. \& Peterson, W. H. (1939). F. Dairy Sci. 22, 63.

Sobel, A. E., Rosenberg, A. \& Engel, E. (1952). F. Nutr. 48, 183 .

Thompson, S. Y., Ganguly, J. \& Kon, S. K. (1949). Brit. $\mathscr{F}$. Nutr. 3, 50.

Tomarelli, R. M., Charney, J. \& Bernhart, F. W. (1946). Proc. Soc. exp. Biol., N.Y., 63, 108.

Worker, N. A. (1956). Brit. F. Nutr. 10, 169.

Worker, N. A. (1957). Brit. F. Nutr. II, 44. 